\title{
Yrityksen saneeraus ja irtisanomisen seuraukset
}

\author{
Soili Keskinen \& Nana Virtanen \\ “Tappiollinen TOP vähentää väestään neljänneksen" \\ (Turun Sanomat 23.10.1996)
}

\begin{abstract}
Viime vuosina ovat paljon puhuttaneet henkilöstön vähentämiset yrityksissä ja organisaatioissa. Yrityksiä ja osastoja on lakkautettu ja henkilöstöä vähennetty. Tässä artikkelissa on tarkoitus luoda kirjallisuuden pohjalta katsaus henkilöstön vähentämiseen irtisanomisen seurausten näkökulmasta. Pohdimme, mitä vaihtoehtoja henkilöstön vähentämiselle on ja mikä merkitys saneerauksella on henkilöstön hyvinvointiin.
\end{abstract}

Käsitteenä henkilöstön irtisanominen voidaan yhdistää organisaation kutistamiseen (downsizing). Saneerauksessa on kyse taloudellisista ja tuotannollisista syistä johtuvasta organisaation uudistamisesta, johon liittyy henkilöstön vähentäminen irtisanomisten muodossa (ks. Lämsä 1998). Esimerkiksi Vollman ja Brazas (1993) määrittelevät kutistamisen yrityksen työvoiman vähentämiseksi. Tämä työvoiman vähentäminen voi olla yhteydessä toiminnan muutos- ja kehittämishankkeisiin, saneeraukseen tai fuusioon. Cameron (1994) jakaa kutistamisen kolmeen ryhmään: systeeminen organisaation kulttuurin kehittäminen "säästäväiseksi", työprosessin kehittäminen sekä irtisanominen. Tässä artikkelissa henkilöstön irtisanominen käsitetään Cameronin (1994) ryhmittelyyn perustuen yhtenä osana organisaation kutistamista. Samoin henkilöstön irtisanomis-käsitettä on käyttänyt tutkimuksessaan mm. Lämsä (1998). Irtisanomisessa työnte- kijä joutuu ilman omaa tarkoitustaan, työnantajan päättämänä, jättämään organisaation (Lämsä 1998).

Henkilöstön saneeraus on muutostilanne, jonka onnistuminen riippuu ratkaisevasti sen toteutustavasta (Vaara 1993, Ylikoski 1993). Muutostilanteessa johtamiskyvyt korostuvat (Darling \& Nurmi 1996, Laakso-Manninen 1998, Myllys 1994). Jos henkilöstön vähentämiseen päädytään, sen toteuttamista, perusteluja ja ajoitusta joudutaan harkitsemaan hyvin huolella (Vollmann \& Brazas 1993).

\section{Henkilöstön saneerauksen vaikut uksia}

Irtisanomisilla on laajoja ja voimakkaita vaikutuksia. Siksi niiden hoitamistapaan tulisi kiinnittää erityistä huomiota. (Huttunen 1997) Sil- 
lä, miten irtisanomiset hoidetaan, on suuri merkitys organisaation tulevalle menestymiselle (Vollman \& Brazas 1993). Eräät ekonomistit ja työpsykologit ovat sitä mieltä, että supistaminen pikemminkin haavoittaa yritystä kuin auttaa sitä, koska on mahdollista, että saneerauksessa poistetaan väärät henkilöt, organisaatiotasot ja toiminnot. Monet supistamiset tulevat kalliimmiksi kuin on osattu olettaa. Pitkäaikaiset kustannukset pikemminkin nousevat kuin laskevat. (Rubach 1996) Huonosti hoidetut irtisanomiset heikentävät työtekijöiden tuottavuutta ja moraalia, jolloin organisaatio on vaarassa menettää merkittävän osan niistä säästöistä, joihin irtisanomisilla pyrittiin (Brockner 1992). Cameron (1994) tutki 30 autoalan organisaatiota, joissa oli pyritty lisäämään tehokkuutta ja tuottavuutta vähentämällä henkilöstöä. Kolmenkymmenen yrityksen joukossa oli ainoastaan viisi yritystä neljän seurantavuoden aikana, joissa suoritustaso kasvoi muutosten toteutuksen jälkeen.

I rtisanominen irtisanomisen vuoksi haavoittaa kokonaislaatua pitkällä aikavälillä. Monesti supistaminen johtaa yhä uusiin supistamisiin, koska kustannusten leikkauksia on jatkettava. Monet yritykset supistavat lyhyen aikavälin taloudellisista syistä ajattelematta pitkäaikaisia vaikutuksia. Yritykset, jotka katsovat supistamisen pitkäaikaisia vaikutuksia, tekevät sen strategisista syistä. Saneerauksen suuri riski on, että toimintatavat eivät muutu: samat työt vain tehdään vähemmällä työvoimalla. Yrityksiin, jotka vähentävät väkeä uudistamatta prosessejaan ja rakenteitaan, jäävän työvoiman työkuorma kasvaa ja seurauksena voi olla henkilöstön burnout. (Rubach 1996, ks. myös Freeman 1994)

Ainoastaan vajaa puolet henkilöstövähennyksiä tehneistä yrityksistä ilmoitti tuottojensa kasvaneen henkilöstövähennysten jälkeen. Henkilöstövähennyksiä tehneistä yrityksistä 80 prosenttia kertoi alentuneesta moraalista. (Filipowski 1993) 30 prosenttia yrityksistä kertoi henkilöstövähennysten lisänneen ylityökustannuksia ja 22 prosenttia huomasi irtisanoneensa vääriä ihmisiä (Greengard 1993). USA:ssa tutkittiin 909 saneerattua yritystä. Osoittautui, että 74 prosenttia ylimmästä johdosta katsoi saneerauksen vau-

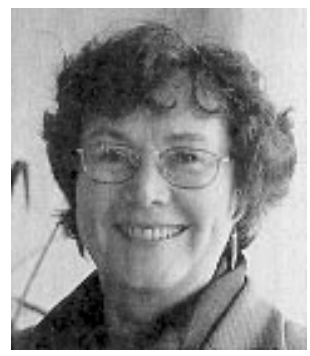

Soili Keskinen

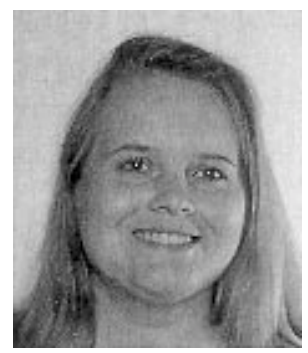

Nana Virtanen

rioittaneen yrityksen henkeä, luotettavuutta ja tuottavuutta. Toisessa tutkimuksessa yli puolet tutkituista 1468 saneeratusta yrityksestä oli sitä mieltä, että saneeraus oli heikentänyt niiden tuottavuutta. Eräässä tutkimuksessa havaittiin, että 71 prosenttia yrityksistä oli ryhtynyt supistamistoimenpiteisiin nostaakseen tuottavuutta, mutta näistä vain 22 prosenttia katsoi saavuttaneensa päämäärän. (Rubach 1996) Suomessa henkilöstön irtisanomista ovat tutkineet mm. Heikkilä (1998), Laakso-Manninen (1998) sekä Lämsä (1998).

\section{Irtisanomisen aiheuttamia ongel m i a}

Irtisanominen on suuri muutos työntekijän elämässä ja voi aiheuttaa kriisin. Kriisi on jonkun loppu ja uuden alku, taitekohta ja ratkaisun hetki. Se voi olla uhka, menetys ja haaste. (Keränen 1994) Kriisi uhkaa toiminnan jatkuvuutta ja vakiintuneita arvoja, se kuluttaa inhimillisiä voimavaroja ja lisää psyykkistä pahoinvointia. Kriisin sävyt voivat olla myös myönteisiä esimerkiksi, kun se johtaa henkiseen uusiutumiseen (Heikkilä 1998). Kriisi laajenee usein muidenkin ihmisten välilliseksi kärsimykseksi. Esimerkiksi irtisanomistilanteessa on irtisanotun lisäksi 
niin sanottuja toissijaisia uhreja usein 15-20 henkeä. Näihin kuuluvat irtisanotun esimies päätöksentekijänä, työpaikalle jäljelle jääneet ja samassa tilanteessa olleet työtoverit, kaipaamaan jäävät asiakkaat sekä perhe- ja ystäväpiiri. (Heikkilä 1998, Saarelma-Thiel 1994)

$\mathrm{T}$ yöpaikan kriisi keskeyttää normaalien rutiinien hoitamisen ja alentaa tuottavuutta. Työyhteisön psyykkinen, sosiaalinen ja fyysinen toimintakyky joutuu koetukselle. Henkilöstö kohdistaa mielipahansa ja kaunansa työpaikalle ja niihin, jotka ovat tilanteesta vastuussa. Työyhteisöstä itsestään tulee helposti traumatisoitunut eikä se pysty vastaamaan sellaisella tuella, jota yhteisön jäsenet ja johtajat tarvitsisivat. Välittömästi kriittisen tapahtuman jälkeen toteutetut toimet voivat ehkäistä tai vähentää posttraumaattisen stressin vaikutuksia. Sen vuoksi on tärkeää, että auttamis- ja tukitoiminnat käynnistetään välittömästi. (Saarelma-Thiel 1994, ks. myös Laakso-Manninen 1998)

Henkilöstön vähentäminen on vaikea asia niin irtisanotuille kuin työpaikkansa säilyttävillekin (Heikkilä 1998). Irtisanominen aiheuttaa organisaatioon jäljelle jäävissä monia reaktioita. Ensinnäkin työmoraali voi alentua, ystävien ja työtovereiden irtisanominen on masentavaa. Jäljelle jäävä ei tiedä, mitä tekisi oman työpaikkansa turvaamiseksi. Välttääkseen itse irtisanottavien listalle joutumista hän saattaa pysytellä mahdollisimman näkymättömissä. Toiseksi työn tuottavuus laskee: työyhteisöön jäävien työmäärä kasvaa. Heille saattaa jäädä epäselväksi, mitä yritys heiltä oikein odottaa. Kolmanneksi epäluulo yritysjohtoa kohtaan lisääntyy. Henkilöstön vähentäminen opettaa, että hyvätkään työsuoritukset eivät takaa pysyvyyttä työyhteisössä. Tämä saa kysymään, voiko johtoon ylipäätään luottaa. Neljänneksi varovaisuus lisääntyy. Riskinottokyky ja luovuus katoavat, koska jäljelle jääneet pelaavat varman päälle ja varovat tekemästä virheitä. (Keränen 1994) Irtisanominen on helpompi hyväksyä silloin, kun koko osasto tai yritys lakkautetaan. Jos irtisanottuja on muutamia tai valikoitu määrä, nämä kysyvät itseltään: Miksi juuri minä? Miksei minusta pidetä? Eikö se riitä, että yrittää parhaansa? Tekevätkö muut kaiken pa- remmin ja nopeammin? Pahimmillaan irtisanottujen joukko voi myrkyttää koko työyhteisön elämän. Niinpä lähtijöille maksetaankin joskus palkkaa sillä edellytyksellä, etteivät he tule irtisanomisaikana töihin. (Brunila 1996)

Y rityksen kannalta irtisanominen ja siihen liitetyt tukipaketit on ehkä näkyvin kustannuserä, mutta huonosti hoidettu irtisanominen voi tuottaa konflikteja, tuottavuusongelmia sekä vinoutumia olemassa olevan henkilöstön rakenteeseen ja sitä kautta se voi tuottaa pitkävaikutteisia koulutuskustannuksia ja joustavuusongelmia. Yhteiskunnallisten kustannusten, kuten uudelleenkoulutuksen, toimeentuloturvan takaamisen ja uudelleentyöllistämisen kohdalla on ratkaisevaa, miten yritys on hoitanut oman vastuunsa. Vaikka yritys selviäisi vähällä, niin yhteiskunta, työnvälitys, sosiaalitoimi ja koulutusorganisaatiot, voivat joutua maksamaan korkean hinnan. Myös perheiden ja yksilöiden maksamat kustannukset on moniulotteinen kysymys. (Jolkkonen ym. 1992, Jolkkonen 1998)

Työhön jääneitä vaivaavat usein syyllisyyden tunteet onnekkaiden joukkoon kuulumisesta (Heikkilä 1998). Lisäksi usein yhteistyöneuvotteluineen ja pitkine irtisanomisaikoineen kuukausia kestävä ylimenovaihe, jolloin jäljelle jäävät ja irtisanotut työskentelevät vielä yhdessä, on tunneherkkä. Se voi hämmentää työpaikan ihmissuhteita ja heikentää työtehoa (Jurvansuu 1998). Tässä tilanteessa voi toistua koko yhteiskunnan mitassa tuttu kahtiajako: toiset ovat ylikuormitettuja lisääntyneiden tehtävien takia, toiset kärsivät alikuormitusta, kun heidän tehtäviään on jo alettu siirtää muille (Saarelma-Thiel 1994).

Jos irtisanomisten aiheuttamat ongelmat jätetään huomioimatta, menetetään kenties juuri ne ihmiset, jotka halutaan pitää yrityksen palveluksessa (Imberman 1989). Huonosti hoidettu saneeraus voi saada aikaan organisaatiosta negatiivisen kuvan siihen ympäristöön, jossa organisaatio toimii. Työntekijät, jotka tuntevat, että heitä on kohdeltu epäoikeudenmukaisesti, tuskin sanovat hyvää sanaa yrityksestä. Tällöin he tekevät yrityksen eteen päin menon entistä vaikeammaksi. (Vollmann \& Brazas 1993) 


\section{Irtis a nom is e n hoitaminen oikein}

Työn laatu voidaan säilyttää, jos irtisanominen hoidetaan oikein, esimerkiksi esimiehiä tukemalla (Keskinen 1998). Laatu voi säilyä, jos yritys kiinnittää huomiota niihin työntekijöihin, jotka jäävät yritykseen. Monet heistä pelkäävät työnsä menettämistä. Heidän sitoutumisensa organisaatioon löystyy. Heitä vaivaa syyllisyyden tunne työpaikan säilymisestä, kun työtoverit joutuvat lähtemään. Ennen kuin organisaatio ja työntekijät selviytyvät eteenpäin, joutuu ylin johto rehellisesti ja kiertelemättä kertomaan, mitä on tapahtunut ja mihin tähdätään. On selvitettävä, että työntekijät ovat arvokkaita. On tärkeää, että organisaatioon jäävät työntekijät saavat kiinnostavaa ja tärkeää työtä, tietoa työstään ja etenemismahdollisuuksistaan, vapautta ja resursseja tehdä työnsä hyvin, palkkaa, joka vastaa työn vaativuutta ja työn vaatimuksia vastaavaa koulutusta. (Rubach 1996)

$\mathrm{H}$ enkilöstöratkaisuissa on tärkeää sopia toimivista ja henkilöstöä kunnioittavista menettelytavoista. Kriisitilanteissa on todettu, että ihmisten mieleen jää pikemminkin se tapa, miten on tullut kohdelluksi, kuin se, mitä sanoja vaikeassa tilanteessa on käytetty. (Saarelma-Thiel 1994) Irtisanomisesta ilmoittaminen on vaativa tilanne esimiehelle (ks. mm. Lämsä 1998). Tämän keskustelutilaisuuden sävy ja sujuminen saattaa olla merkityksellinen irtisanotun itsetunnon ja tulevaisuuden hahmottamisen kannalta. Esimiesten konsultointiryhmistä, joissa esimiesten on mahdollista työstää heihin kohdistuvia irtisanomisen aiheuttamia kiukun, harmin, vihan ja pettymyksen tunteita, on saatu hyviä kokemuksia (Keskinen 1998). Työntekijän kohtelu irtisanomistilanteessa sävyttää sitä, minkälaisen kuvan asianomainen viestittää työpaikastaan muille, ja sitä haluavatko työtoverit jatkaa tässä työpaikassa tai haluaako hän suositella sitä muille. (Saarelma-Thiel 1994) Organisaatiolla on käytettävissään keinoja, joilla autetaan työntekijöitä sopeutumaan nopeammin työn menetykseen. Näitä ovat tiedotus irtisanomisista, erilaiset palkkaetuudet, koulutus- ja harjaannuttamisohjelmat, outplacement avustus (= irtisanotut voivat op- pia kuinka löytää uusia työmahdollisuuksia ja markkinoida itseään tehokkaammin mahdollisille työnantajille), selvät, suorat ja empaattiset ilmoitukset irtisanomispäätöksistä, huomio ja huolenpito työhön jäävistä, inhimillisten resurssien suunnittelukäytännöt (mietitään vaihtoehtoja pysyville, laajoille irtisanomisille, jotta pysyvästi irtisanottavien työntekijöiden määrä olisi mahdollisimman vähäinen) sekä yhteistyö yksityisen ja julkisen sektorin kanssa. (Feldman \& Leana 1994, Heikkilä 1998, Jolkkonen 1998, Laakso-Manninen 1998)

Organisaation tulisi rakentaa riittävät turvaverkot tukipalveluiden muodossa lähtijöille ja jääville. Näitä ovat esimerkiksi riittävä aika sopeutua tietoon irtisanomisesta, taloudelliset edut tukipakettien muodossa, psykologinen tuki, ryhmässä tai yksilöllisesti tapahtuva muutosvalmennus kaikille, uudelleenkoulutusmahdollisuudet lähtijöille ja riittävä koulutus jääjille sekä uudelleensijoituspalvelut. (Cameron 1994) Schweigerin ja Denisin (1991) mukaan riittävä tieto muutoksista vähentää työntekijöiden stressiä, koettua epävarmuutta, poissaoloja ja työtyytyväisyyden laskua. Yleensä työntekijöiden osallistaminen ja tiimitoiminta sekä yksiköissä että yli yksikkörajojen edesauttavat muutosten toteutusta ja ennustavat kielteisten vaikutusten vähäisyyttä (Lohrum 1996).

$\mathrm{K}$ un yritys vähentää työvoimaansa, se loukkaa äljelle jäävän henkilöstön turvallisuuden ja oikeudenmukaisuuden tajua. Saneerauksen jälkihoito on vähintään yhtä tärkeää kuin itse saneeraus. (Keränen 1994) Työttömyysuhassa olevien lisäksi myös työpaikalle jäävä henkilöstö kokee työkriisin vaikutukset. Osa työyhteisön ammattitaidosta katoaa työpaikalta ja rutiinien hoito vaikeutuu henkilöstön supistuessa. Tällöin jäljelle jäävien yhteisöllinen työkyky voi ratkaisevasti heiketä. Työn vaatimukset ja työkuorma usein kasvavat, kun toimenkuviin yhdistetään poislähteneiden tehtäviä eikä turhia tehtäviä karsita. Säästöjen vuoksi joudutaan usein vielä tulemaan toimeen vajaalla henkilöstöllä. Pitkään jatkuessaan tällainen tilanne lisää työuupumuksen mahdollisuutta. Oman työn hallinnan tunne heikkenee, jos työnopastusta ja perehdytystä 
uusiin osaamisalueisiin ei ole asianmukaisesti järjestetty. Uudet tehtävät edellyttävät oppimista ja monitaitoisuutta, ammatillista joustoa, eivätkä lähtijät aina ole halukkaita perehdyttämään jäljelle jääviä entisiin tehtäviinsä. (Saarelma-Thiel 1994)

Pankkien tukimuotoihin ovat kuuluneet mm. työnhakukeskukset, psykologin palvelut, tukipaketit, keskusteluapu, työryhmät, työnohjaus, työterveyshuolto, tiedotustilaisuudet, koulutustuki, työvoimaneuvonta ja vapaaehtoisjärjestöjen tarjoamat toimintamahdollisuudet. (Brunila 1996, Heikkilä 1998, Huttunen 1997, Jolkkonen 1998, Pakkala 1997)

Tukipalvelujen tarjoaminen ei ole vielä riittävä toimenpide saneerauksen hyvin hoitamiseksi. Organisaatioon täytyisi kyetä luomaan ilmapiiri, jossa tarjottuja tukipalveluja myös käytetään. Suunniteltaessa tukitoimia kannattaisi keskustella henkilöstön kanssa siitä, millaisia tukimuotoja henkilöstö kokee tarvitsevansa. (Huttunen 1997) Tukipakettiin voi liittyä myös negatiivisia vaikutuksia. Huttusen (1997) tutkimuksessa työntekijäpuolen ajatukset tukipaketista olivat ristiriitaiset. Toisaalta he olivat tyytyväisiä siihen, mutta kuitenkin tukipaketti nähtiin pääasiallisesti kaunisteltuna irtisanomisena ja sen ottamiseen koettiin liittyvän joskus painostamista työnantajan ja työtovereiden taholta. Ongelmana on työntekijäpuolen mukaan ollut se, että ihmiset eivät aina osaa tai uskalla käyttää tarjottuja tukimuotoja (Huttunen 1997). Olisikin syytä kiinnittää huomiota keinoihin, joilla saataisiin työntekijät rohkaistuksi käyttämään tukimuotoja. Lisäksi tutkimustulosten perusteella (LaaksoManninen 1998) yksilöiden erot näyttävät saavan merkittävän roolin. Yksilöiden väliset erot vaikuttavat niin voimakkaasti, ettei yksinkertaisia neuvoja ohjelmien käyttökelpoisuudesta voida antaa.

\section{Millä ehdoilla irtisanominen kannattaa?}

$\mathrm{V}_{\mathrm{s}}$ ollmannin ja Brazasin (1993) mielestä irtisanomisen tulisi olla vasta viimeinen keino taantuvan organisaation pelastamiseksi. Ennen ir- tisanomisiin ryhtymistä on olemassa useita vaihtoehtoisia toimintatapoja. Näitä ovat ylitöiden rajoittaminen, uudelleensijoitus ja uudelleenkoulutus, osa-aikaistaminen, työn jakaminen, palkattomat vapaat, lyhennetty työviikko ja palkan alennukset. Settles (1988) mainitsee näiden lisäksi myös eläkeratkaisut ja tuhlauksen vähentämisen vaihtoehdot. Myös Freemanin (1994) mielestä saneerauksessa pitäisi välttää irtisanomisia ja muita kovia otteita. Saattaa kuitenkin olla, että irtisanomiset osoittautuvat välttämättömäksi.

Esimerkiksi pankit ovat käyttäneet melko vähän erilaisia vaihtoehtoja irtisanomisille. Ainoa laajemmin käytetty vaihtoehto on ollut työntekijöiden osa-aikaistaminen. Osa-aikaistamisen lisäksi pankeissa on jonkin verran tarjottu mahdollisuutta uudelleensijoitukseen tai uudelleenkoulutukseen. Sen sijaan pankkien tukitoimet ovat olleet varsin kattavat. (Heikkilä 1998, Huttunen 1997, Jolkkonen 1998)

$\mathrm{K}$ annattaako irtisanominen? On osoitettu, että irtisanomisilla on monia haitallisia vaikutuksia organisaatiolle (ks. Brockner 1992, Cameron 1994, Filipowski 1993, Greengard 1993, Rubach 1996). On siis syytä miettiä, mitkä ovat irtisanomisten perusteluja. Joskus, kuten kun yritys lopetetaan, irtisanomisille ei ole vaihtoehtoja. Tällöin on tärkeää, että organisaatio huolehtii irtisanotun henkilöstön hyvinvoinnista $\mathrm{mm}$. tarjoamalla erilaisia tukimuotoja. On todettu (ks. esim. Feldman \& Leanan 1994), että on keinoja, joilla voidaan minimoida henkilöstön tuntema pahoinvointi irtisanomistilanteessa.

Kriisissä, kuten irtisanomistilanteessa, yhteisö tarvitsee tilaa tunteille sekä ilmapiiriä, joka lujittaa jäsenten itsetuntoa. Tavoitteeksi voidaan asettaa, että muutokset toteutetaan ihmistä kunnioittavalla tavalla. Erityisesti tavoiteltavaa olisi, että jokainen pääsisi osallistumaan itseään koskevaan päätöksentekoon. Myös ammattitaidon hyödyntämisestä, osaamisen jatkokehittämisestä ja avoimesta tiedon kulusta on huolehdittava. (Viitamaa-Tervonen \& Mietala 1994) Irtisanomisen hoitaminen ja läpivieminen oikeudenmukaisesti yksilöä kunnioittaen vähentää hyvinvoinnin häiriöitä (Heikkilä 1998). 
Irtisanomisen aikana ja sen jälkeen tulisi pohtia sitä, mitkä ovat työntekijän oikeudet ja vastaavasti mikä on työnantajan vastuu näissä toiminnoissa. Työntekijällä on oikeus informaatioon, joka koskee hänen työtään, yritystään tai uraansa. Työntekijän tulisi saada osallistua päätöksiin, jotka vaikuttavat hänen työtilanteeseensa. Puuttuva työntekijöiden oikeuksien kunnioitus johtaa sitoutuneisuuden, lojaalisuuden, vastuullisuuden ja luottamuksen puutteeseen. (Werhane 1988) Irtisanotun työntekijän vastuulla on käyttää tarjottuja tukimuotoja, jäsentää urasuunnitelmaansa ja mahdollista uudelleen kouluttautumistaan.

I rtisanomiset ovat olleet 1990-luvulla monien suomalaisten yritysten ja myös julkishallinnon ratkaisuja taloudellisiin ongelmiinsa. Erilaisia tilastoihin pohjautuvia selvityksiä on tehty irtisanottujen uudelleen sijoittumisesta. Sen sijaan kasvatustieteellisestä näkökulmasta on huomattavan vähän tutkimusta esimerkiksi siitä, millaiset koulutusjärjestelmät olisivat mielekkäimpiä sekä irtisanotuille että organisaation jäsenille. Tutkimuksia ei myöskään ole tehty siitä, millaisin koulutuksellisin keinoin organisaatioon jääneet tehokkaimmin omaksuvat tehtävät, joita irtisanomisten jälkeen on hoidettava. Irtisanomiset saattavat vaurioittaa organisaation imagoa. Eräänä ratkaisuna tähän on käytetty outplacementtoimintaa, mikä on myös irtisanotuille työntekijöille vahva kädenojennus ahdistavassa muutostilanteessa. Outplacement-toiminnan prosessi ja vaikuttavuus ovat nekin tutkimattomia alueita.

\section{Lähteet}

BROCKNER, J. (1992) Managing the Effects of Layoffs on Survivors. California Management Review 34 (2), 9-28

BRUNILA, M. (1996) Pankeissa menossa jatkuva kriisityö. Työ terveys turvallisuus 26 (7), 26-27.

CAMERON, K. S. (1994) Strategies for Successful Organizational Downsizing. Human Resource Management 33 (2), 189-211

FELDMAN, D. C. \& Leana, C. R. (1994) Better Practices in Managing Layoffs. Human Resource Management 33 (2), 239-260.

FILIPOWSKI, D. (1993) Downwizing Isn't Always Rightsizing. Personnel Journal 72 (11), 71.
FREEMAN, S. J. (1994) Organizational Downsizing as Convergence or Reorientation: Implications for Human Resource Management. Human Resource Management 33 (2), 213-238

GREENGARD, S. (1993) Don't Rush Downsizing: Plan, Plan, Plan. Personnel Journal 72 (11), 64-76.

HEIKKILÄ, T. (1998) Muutosmyrsky: pankkifuusio työntekijöiden kokemuksena. Tuotantotalouden osasto. Raportti no 7. Teknillinen korkeakoulu. Helsinki.

HUTTUNEN, M. (1997) Eettinen johtaminen irtisanomistilanteissa. Pro gradu -tutkielma. Yrityksen taloustieteen ja yksityisoikeuden laitos. Yrityksen hallinto. Tampereen yliopisto.

IMBERMAN, W. (1989) Managers and Downsizing. Business Horizons September-October, 28-33

JOLKKONEN, A., Koistinen, P., Kurvinen, A. (1992) Yrityksen strategia ja henkilöstön valinnat. Teoksessa Jolkkonen, Koistinen, Kurvinen, Linnakangas ja Suikkanen. Lopputili ja saldo. Tutkimus Postipankin maksupalvelutoiminnon keskittämisestä ja henkilöstön sopeutumisesta. Karjalan tutkimuslaitoksen monisteita n:o 9. Joensuun yliopisto, 25-50.

JOLKKONEN, A. (1998) Paikan vaihto. Tutkimus irtisanomisuhan alaisten naisten työmarkkinastrategioista ja paikallisista työmarkkinoista. Joensuun yliopiston yhteiskuntatieteellisiä julkaisuja n:o 29 .

JURVANSUU, A. (1998) Esimieskoulutuksella potkua tiimityöhön. Tiimityöhön liittyvien käsitysten muuttuminen tiimitoimintaa aloittavissa pankkiorganisaatioissa. Kasvatustieteen laudaturtutkielma. Turun yliopisto

KERÄNEN, S. (1994) Työelämän muutokset ja niistä selviytyminen. Mannerheimin Lastensuojeluliitto. Suomen Mielenterveysseura. Suomen Punainen Risti. Porvoo: $T^{*} T$.

KESKINEN, S. (1998) Saneeraukseen liittyvien kokemusten jäsentäminen esimiesten konsultaatioryhmissä. Esitelmäabstrakti (suullinen esitelmä) kongressijulkaisussa XX Nordic congress of psychology \& Psykologia '98, Helsinki 26. - 29.8.1998.

LAAKSO-MANNINEN, R. 1998. Human resource management in downsizing. A case stydy of the effects of specific HRM actions in downsizing from the viewpoint of personnel and managers. Turun kauppakorkeakoulun julkaisuja sarja A-5.

LOHRUM, C. (1996) Post-acquisition integration: Towards an understanding of employee reactions. Ekonomi och samhälle. Swedish school of economics and business administration, Helsinki.

LÄMSÄ, A-M. 1998. Hyötyä, velvollisuuksia ja tunteita - johtajien kokemuksia henkilöstön irtisanomisesta. Jyväskylän yliopisto. Taloustieteellinen osasto. Julkaisuja n:o 115

MYLLYS, K. (1994) Bank Managers'Agendas: Thoughts and Actions in a Crisis Situation. Yrityksen taloustieteen ja yksityisoikeuden laitos. Sarja Al tutkimuksia 42. Tampereen yliopisto

PAKKALA, K. (1997) Tukiohjelma suuressa henkilöstövähennyksessä. Kokemuksia Meritasta. Työterveyslääkäri 15 (2), 197-199

RUBACH, L. (1996) Mitä tapahtuu työn laadulle, kun väkeä vähennetään? Yritystalous 54 (1), 33- 38.

SAARELMA-THIEL, T. (1994) Kriisistä ylös - työpaikan 
valmius ja selviytyminen. Työterveyslaitos. Painotalo Miktor, Helsinki.

SCHWEIGER, D. M. \& Denisi, A. S. (1991) Communication with employees following a merger: A longitudinal field experiment. Academy of Management Journal 34 (1), 110-135.

SETTLES, M. F. (1988) Humane Downsizing: Can It Be Done? Journal of Business Ethics 7 (12), 961-963

VAARA, E. (1993) Finnish-Swedish Mergers and Acquisitions: An Empirical Analysis of Success. Teollisuustalouden ja työpsykologian laboratorio. Raportti no 147. Helsingin teknillinen korkeakoulu.

VIITAMAA-TERVONEN, O. \& Mietala, O. (1994) Työyhteisön kriisit ja niiden kohtaaminen. Tampere: Algraphics Oy Tamprint.
VOLlMAN, T. \& Brazas, M. (1993) Downsizing. European Management Journal 11 (1), 18-29.

WERHANE, P. H. (1988) Two Ethical Issues in Mergers and Acquisitions. Journal of Business Ethics $7(1 \&$ 2), 41-45

YLIKOSKI, M. (1993) Työyhteisö muutosmurroksessa Ihmisyys muutoksen kohtaamisessa ja johtamisessa. Työturvallisuuskeskus. Mikkeli.

Artikkeli saapui toimitukseen maaliskuussa 1999. Se hyväksyttiin julkaistavaksi 7.6.1999. 